\title{
MORAL DEVELOPMENT ON INMATES AS THE EFFORTS TO PREVENT RECIDIVISTS
}

\author{
Nurhayati $^{1 *}$; Eny Kusdarini²; Usman Hamimu ${ }^{3}$ \\ 1,2Pendidikan Pancasila dan Kewarganegaraan, Universitas Negeri Yogyakarta \\ Jl. Colombo Yogyakarta No. 1, Karang Malang, Caturtunggal, Sleman, Daerah Istimewa Yogyakarta 55281, Indonesia \\ ${ }^{3}$ SMP Negeri Satap 1 Tongkuno \\ Desa Kotano Wuna Kecamatan Tongkono Kabupaten Muna, Kota Raha, Sulawesi Tenggara 93232, Indonesia \\ 'nurhayati6pasca.2018@student.uny.ac.id; 2enykusdarini@uny.ac.id; ’usmanhamimu3@gmail.com
}

Received: 02 ${ }^{\text {nd }}$ February 2021/ Revised: $28^{\text {th }}$ April 2021/ Accepted: $28^{\text {th }}$ April 2021

How to Cite: Nurhayati., Kusdarini, E., \& Hamimu, U. (2021). Moral development on inmates as the efforts to prevent recidivists. Humaniora, 12(3), 173-178. https://doi.org/10.21512/humaniora.v12i3.7006

\begin{abstract}
The research aimed to comprehend the guidance given to inmates to build their mental, good morals, and to be able to absorb positive values of life demands based on the values, norms, and morals implemented in society to prevent recidivists. The problem formulation was how the forms of development of inmates in the Kendari Class IIA Prison of Correctional Institution prevent recidivists. The research was conducted at Kendari Class IIA Prison of Correctional Institution. Descriptive research and a qualitative approach were implement. There were three informants and respondents: the Head of the Kendari Class IIA Prison, the Head of Class IIA Kendari Prison Development, and the Head of Community Guidance and Care of Class IIA Prisons in Kendari, and 30 inmates as respondents and recidivists. The data were collected by conducting library research and field research that consisted of observations, interviews, questionnaires, and documentation. The results reveal that the forms of guidance for inmates in Kendari Class IIA of correctional officers to prevent recidivists are religious awareness building, intellectual capacity building, legal awareness building, and integration with the community (social). Applying a guidance pattern for the inmates is expected to be a part of the tools for correctional officers, especially for those who work in correctional institutions.
\end{abstract}

Keywords: moral development, inmates, recidivist prevention

\section{INTRODUCTION}

Criminal acts often make the community feel unsafe, as a social phenomenon in the community, without thinking of the victims' social status, economic conditions, and the area. Kartono (2011) has defined crime as a form of behavior that contradicts human morals, harms society, the nature of the association, and violates the law, especially criminal law. A criminal act is conducted by a criminal or perpetrator, a person or group of people who violates criminal law or regulations where the violation is identified and punished in a judicial process (Sudarto, 2010). Punishments for the criminals, both in the form of fines and correctional systems, are intended to provide compensation to the victims, as well as provide a deterrent effect for the perpetrators.

A criminal who has been proven to commit a criminal act and has limited rights as a citizen in the correctional institution is called an inmate. The role of the correctional institution itself is regulated in Article 2 of Law No. 12 of 1995, about protecting and fostering an inmate to be a human, aware of mistakes, fixing themselves, not repeating criminal acts, and can be accepted by the social environment. Based on data of the Director-General of Corrections (ditjenpas. go.id), in October 2019, in inmates in Class IIA of correctional institutions in Kendari, there were 591 inmates, consisting of 91 female inmates and 500 male inmates. 
The system, which is expected to be able to provide a deterrent effect and a significant change to the perpetrators, is very difficult to achieve. This is proven by the number of inmates who return to prison for the second time for committing crimes after being released. The number of recidivist cases in Indonesia is reflected in the abundance of news about repeated criminal acts in several regions in Indonesia. Repetition of criminal acts occurs in Jakarta, such as motorbike theft done by two people, where the perpetrators have previously done armed robbery and murder (Hamanongan, 2018). Repetition of criminal acts also occurs in East Java, such as the arrest of a criminal gang who committed theft and robbery of bank customers, and a perpetrator is a person who has previously become a prisoner for a similar case (Madia, 2018). The case of repeating criminal action in Semarang even occurs only ten days after the three perpetrators committed crimes. During the ten days of his freedom, the perpetrators have committed three crimes in three different locations, such as the theft of an empty house and robbery two times. One of them is injuring the victim (Recidivist free days are back in action three times, 2017). The number of cases of repetition of criminal acts proves that the purpose of correctional punishment in Indonesia, which aims to produce a deterrent effect, has not been optimally implemented.

The role of correctional institutions is expected to be able to improve the inmates not to repeat the actions that are contrary to the law, social, and religious, since correctional institutions are not only a place to fund people but also a place to build and educate the convicted. After completing the criminal, they can fix their life outside the correctional institution as a good citizen and obey the law. The number of many patterns of development in the correctional institution cannot be separated from a dynamic whose purpose is to make the inmates become citizens with provisions in life after being a prison in the correctional institution.

Repetition of criminal acts is commonly referred to as recidivism (Huss, 2008). Someone is called a recidivist if the person returns to prison within a certain period, two or three years after the first punishment (become a prison) (Ruggero, Dougherty, \& Klofas, 2015). Reconstruction or re-incarceration is another measurement used in judging a person as a recidivist. Reconciliation can be defined as a situation in which a court determines that a person has committed a new crime, with or without a punishment (Ruggero, Dougherty, \& Klofas, 2015). Re-incarceration can be defined as an arrest that makes a person to be a prisoner. Prison is defined as detention to get a deterrent effect on criminals or inmates (Cooper, Durose, \& Snyder, 2014). Inmates who are previously imprisoned are more likely to be involved in an emotionally oriented crime and uncontrollable behavior (LaCourse et al., 2019).

The increased number of people returning to criminal activity and the high rate of recidivists are shreds of evidence of the failure of the Correctional
Institution system. The high level of inmates' recidivism indicates that the Correctional Institution's education facilities have not improved the prisons' character and changed their attitude (Susetyo, 2013; Abdullah, 2016). Hence, with moral development, it is hoped that the inmates can carry out their role as good citizens to give participation in the development of the state after leaving the prison, to become good citizen who possesses several civic competencies, such as citizenship knowledge, citizenship skills, and civic values. Meanwhile, the inmates' mastery of citizenship competencies can be guided.

Education in public institutions can create a conducive atmosphere to make the inmates have dignity and care for their fellow humans (Behan, 2007) since people have mistakes. Sometimes the same mistakes will be repeated, hoping there will be guidance for the Class IIA Prison of Correctional Institution Kendari. The purpose of the guidance is to make the inmates be able to improve themselves, and do not repeat the criminal acts (recidivism), and be able to interact with communities. The implementation of moral guidance is conducted with various coaching programs.

The research aims to find out, describe, and analyze how the prisoner development program is implemented in the Class IIA Prison of Correctional Institution in Kendari. The guidance given to the inmates is expected to build the inmates' mental and have good morals and be able to absorb positive values from the guidance program that has been given.

\section{METHODS}

A descriptive method and a qualitative approach are implemented to describe the forms of development of inmates in Class IIA Prison of Correctional Institution Kendari in preventing recidivists. The stages of qualitative data analysis are adopted from Huberman and Miles (2002), consist of three activities: data reduction, data display, and drawing conclusions or verifying.

There are several techniques in collecting data: (1) observation, as a way of collecting data in the form of direct or indirect observations regarding forms of guidance to inmates in Class IIA Prison of Correctional Institution Kendari. (2) Direct interviews with related parties, namely informants and respondents. The informants are the officers of Class IIA Prison of Correctional Institution Kendari, while the respondents are the Correctional Assistants and the recidivists. (3) Questionnaires, by using a set of questions that is systematically submitted to respondents to obtain data of forms of guidance in Class IIA Prison of Correctional Institution Kendari. Then, the data are processed qualitatively and descriptively by explaining the reality obtained from the interview results. Furthermore, the data are studied with the problems descriptively to answer the research problem. 


\section{RESULTS AND DISCUSSIONS}

The correctional system is a development of the implementation of the prison system for inmates, by not only providing inhuman punishments but providing lessons to improve the inmates' character and not repeating their mistakes, to be accepted by society (Wardhani, Hartati, \& Rahmasari, 2016). The correctional system is based on the principles of Pancasila. Meanwhile, the guidance aims to ensure that inmates will not repeat their actions (crimes), live in a normal society, and participate in the development. The correctional institution seeks to foster and educate the inmates to regret their actions and develop themselves, upholding moral values and being fostered in terms of independence as a life goal in the future, when they are free from prison. In achieving the goal of correctional punishment, it requires motivation from correctional officers and the community in a sustainable and integrated manner, both when the prisoner is in a correctional institution or outside the correctional institution (Maryanto, Rahmawati, \& Rini, 2014; Utami, 2017; Wulandari, 2012). Based on the Decree of the Minister of Justice of the Republic of Indonesia Number: M.02-PK.04.10 of 1990 concerning forms of guidance, Class IIA Prison of Correctional Institution Kendari provides several forms of prison to prevent recidivists.

Personality development for the inmates aims to make them become responsible citizens, such as building their religious awareness, enhancing their intellectual abilities, fostering their legal awareness, and integrating themselves into the community (social). Fostering religious awareness is needed to strengthen the inmates' faith, and they can be aware of the consequences of right actions and wrong actions. The results of questionnaires to the inmates on how to carry out religious awareness development in Class IIA Prison of Correctional Institution Kendari is presented in Table 1.

Table 1 The Implementation of Religious Awareness Development in Class IIA Prison of Correctional Institution Kendari

\begin{tabular}{lcc}
\hline ASSESSMENT & Frequency (F) & Percentage (P) \\
\hline Good & 24 & $80 \%$ \\
Not good & 6 & $20 \%$ \\
\hline Total & $\mathbf{3 0}$ & $\mathbf{1 0 0 \%}$ \\
\hline
\end{tabular}

(Source: Results of questionnaire processing, 2019)

Based on the data, the development of religious awareness is well received by the inmates. Moreover, $80 \%$ of 24 respondents have responded that the religious awareness coaching carried out in Class IIA Prison of Correctional Institution Kendari is running well, and $20 \%$ of the six respondents give unfavorable responses. From the respondents' answers and interviews, it can be concluded that one form of guidance in Class IIA Prison of Correctional Institution Kendari, namely the development of religious awareness, can be well accepted as an effort to prevent recidivists from occurring. Herianto has stated that (interviewed on 29 September 2019):

"The development of religious awareness that is carried out in Class IIA Prison of Correctional Institution Kendari is accepted well, and the inmates can reflect on everything they have done and realize the consequences of their actions and makes regret in their hearts, and they return to their Lord."

In line with the Head of Community Guidance and Care Class IIA Kendari, Mr. Mustar Taro has stated that (interviewied on 9 September 2019):

\begin{abstract}
"For the development of religious awareness, we hope that the inmates in Class IIA Prison of Correctional Institution Kendari can be the individuals who conscious and regret with what they have done. Religion will always be in line with morals and attitudes, since the better the religion, the better the morals. The tutors/ coaches who handle the inmates are usually taken outside the Correctional Institution."
\end{abstract}

Religious obedience will affect the humans' behavior, as well the inmates in Class IIA Prison of Correctional Institution to prevent recidivists. During the last twenty years, the researchers have paid a lot of attention to the relationship between religion and crime, and they argue that religion tends to have an influence, since religion can hinder evil behavior (Adamcxyk, Freilich, \& Kim, 2017; Berry, 2005; Johnson et al., 2000). Religion can reduce participation in criminal activity in two ways: first, religion as self-control; second, religions are social controllers (Sumter et al., 2018). With the development of religious awareness, it is expected to strengthen their faith, especially to make the inmates be aware of the consequences of right actions and actions that violate the law.

Fostering legal awareness is carried out by providing legal education to achieve a high level of legal awareness as community members are aware of their rights and obligations to uphold law and justice, protect human dignity, order, legal certainty, and the behavior of Indonesian citizens who understand the law. Fostering legal awareness Class IIA Prison of Correctional Institution Kendari is carried out by providing legal counseling that aims to achieve a high level of legal awareness so that members of the community are aware of their rights and obligations to participate in upholding law and justice, protection of human dignity, order, tranquility, legal certainty, and the formation of the behavior of every Indonesian citizen who obeys the law. The development of legal awareness based on the results of questionnaires distributed to the inmates on how to implement 
national and state awareness development in Class IIA Prison of Correctional Institution Kendari is presented in Table 2.

Table 2 Implementation of Class IIA Kendari Prison Legal Coaching

\begin{tabular}{lcc}
\hline ASSESSMENT & Frequency (F) & Percentage (P) \\
\hline Good & 22 & $73,3 \%$ \\
Not good & 8 & $26,6 \%$ \\
\hline Total & $\mathbf{3 0}$ & $\mathbf{1 0 0 \%}$ \\
\hline
\end{tabular}

(Source: Results of questionnaire processing, 2019)

Based on Table 2, there are 22 respondents, or $73,3 \%$, have responded that the personal development carried out in Class IIA Prison of Correctional Institution Kendari is good, and eight people, or 26,6\%, give unfavorable responses. Hence, it really needs to be implemented, as in line with Mustar Taro, the Head of Community Guidance and Care (interviewed on 9 September 2019).

"A prisoner is part of a member of society who inhabits a country, even though they violate or deviate from the law, we, who are entrusted with responsibility for this matter, try to make the inmates aware of their rights and obligations to help enforce law and justice, and protection on humans' dignity, peace, legal certainty, and the formation of the behavior of every Indonesian citizen who obeys the law, so criminal acts do not occur again."

The interview result is in line with Lukman (interviewed on 29 September 2019):

"The implementation of legal awareness development is intended even if the inmates, have violated the law, they are not always judged as violators of the law, but they are nurtured and that they can realize the importance of the law, and they realize their rights and obligations to become law-abiding public behavior."

The development of legal awareness of inmates in prisons is carried out to achieve a high level of awareness. As members of society, the rights agreed are to uphold law and justice, maintain human dignity, peace, legal certainty, and the formation of relations of every Indonesian citizen. Legal education can form a family with legal awareness that is fostered in prison or after returning to the community (Tjahjati, 2012). Law is the embodiment of values aimed at regulating humans' behavior to prevent violations of the law (Prabawa \& Suardana, 2020). Everyone is required to understand the law and institutions, so legal awareness is built from actions and experiences
(Iriani, 2019). With the development of legal awareness for correctional institutions, it is expected that they can provide knowledge and understanding of legal awareness without violating legal rules.

The development of intellectual abilities is needed in supporting the positive activities during the coaching period. With the development of intellectual abilities, it is hoped that the inmates can improve their critical thinking abilities, as stated by the Head of Community Guidance and Care for the city of Kendari:

"We know that they have different intellectual abilities, so with intellectual ability development, we want to prevent the inmates to become stiff or imperceptible, but what we hope is their thinking ability will increase and they can carry out positive activities the guidance, and they can be developed in the community when they are released." (Mustar Taro, interviewed on 9 September 2019).

The interview result is in line with the statement of the Head of Correctional Institution.

"The development of the inmates' intellectual abilities aims to increase their thinking ability, they can avoid crime actions, and they can respond to all problems well (positively) both in the family environment and in the community." (Lukman, interviewied on 29 September 2019)

In line with the interview result, the information that strengthens the respondents' response is in Table 3.

Table 3 Implementation of Intellectual Development in Class IIA Prison of Correctional Institution Kendari

\begin{tabular}{lcc}
\hline ASSESSMENT & Frequency (F) & Percentage (P) \\
\hline Good & 21 & $70 \%$ \\
Not good & 9 & $30 \%$ \\
\hline Total & $\mathbf{3 0}$ & $\mathbf{1 0 0 \%}$ \\
\hline
\end{tabular}

(Source: Results of questionnaire processing, 2019)

Based on Table 3, there are 29 respondents, or $70 \%$ respondents, in Class IIA Prison of Correctional Institution Kendari are good in implementing the guidance, while one person, or $30 \%$, gives unfavorable responses. Thus, based on the interview results and the respondents, it can be concluded that one of the forms of development in Class IIA Prison of Correctional Institution Kendari is the development of the intellectual abilities of the inmates, which aims to increase their thinking ability so that they can think positively about everything, for example, problems in the family and the community, wherever they are. In line with Ningtyas, Gani, and Sukanto's (2013) research, the development of a person's intellectual 
abilities can affect human relationships and behavior in their environment.

Interaction between individuals and other individuals is essential in society. Guidance for integrating oneself with society (social) provides an opportunity to develop the inmates' personalities. In prison, they are continuously fostered to be worthy of worship and to be able to carry out social efforts in mutual cooperation, so when they return to their community, they have positive characteristics and participation in the development. Head of the Kendari City Prisoner Development Section has stated that:

"Social guidance is carried out outside the Correctional Institution, and carried out by prison officers to invite the inmates to society and mingle with the community through cooperation such as fixing roads, irrigation, and cleaning the village as well as encouraging the social spirit." (Herianto, interviewed on 28 September 2019)

The interview result is in line with the statement of the Head of the Correctional Institution.

"The objectives of social guidance are to be able to assist inmates in developing good patterns of attitudes and behavior in community, and they can build a self-confidence in adapting to society, resulting in a sense of social responsibility in social life. Besides, it aims to create harmony in the relationships of the community, family, officers, and inmates themselves. And the last is to see the degree of discipline of inmates in obeying the regulations set by the Penitentiary." (Lukman, interviewed on 29 September 2019)

Based on the interview results, it can be concluded that social coaching in Class IIA Prison of Correctional Institution Kendari is an effort to integrate inmates with the community. It has an orientation and the intention of developing a pattern of attitudes towards inmates in the form of fostering self-confidence and social responsibility, to what extent they have made changes and developments in obeying the rules and norms, both in the correctional institution and in the community, after the completion of their term.

Table 4 The Implementation of Self Integration Development with Community (Social) Correctional Class IIA Kendari

\begin{tabular}{lcc}
\hline ASSESSMENT & Frequency (F) & Percentage (P) \\
\hline Good & 25 & $83,3 \%$ \\
Not good & 5 & $16,6 \%$ \\
\hline Total & $\mathbf{3 0}$ & $\mathbf{1 0 0 \%}$ \\
\hline
\end{tabular}

(Source: Results of questionnaire processing, 2019)
Based on the respondents' responses in Table 4, there are 25 respondents, or $83,3 \%$, have responded that the personal coaching carried out in Class IIA Prison of Correctional Institution Kendari is good, and five people, or $16,6 \%$, give unfavorable responses. Thus, if it is connected with the data from the interview results, it can be concluded that in the implementation of integrating with the community, society guidance (social) can create pleasure, intimacy, and harmony between inmates and other inmates, and between inmates and officers of social institutions, and take advantage of an atmosphere of intimacy harmony. This is in line with Nasaruddin and Syarifuddin's (2018) research about integration with the community (social) guidance. It aims to improve the relationship of inmates with the community in their environment later, after completing the punishment in prison.

\section{CONCLUSIONS}

The implementation form of training for prisoners is in an effort to prevent recidivists from occurring in Class IIA correctional facilities in Kendari City, namely center for the development of religious awareness, development of intellectual skills, development of legal awareness, and guidance to integrate themselves with the community (social). Guidance for prisoners is carried out with the hope of changing the orientation of a correctional facility from a consumptive institution to a productive institution that can heal a sense of self-confidence, care for others and strive to be a good citizen, because prisons have the potential for human resources in the form of prison labor. However, there are some constraints of time limitations, internal factors of the prisoners, and facilities. Meanwhile, the limitation of this research lies in the lack of the number of respondents, which is only 30 people.

\section{REFERENCES}

Abdullah, R. H. (2016). Urgensi penggolongan narapidana dalam lembaga pemasyarakatan. FIAT JUSTISIA: Jurnal Ilmu Hukum, 9(1), 49-60. https://doi. org/10.25041/fiatjustisia.v9no1.587.

Adamczyk, A., Freilich, J. D., \& Kim, C. (2017). Religion and crime: A systematic review and assessment of next steps. Sociology of Religion: A Quarterly Review, 78(2), 192-232. https://doi.org/10.1093/ socrel/srx012.

Behan, C. (2007). Context, creativity, and critical reflection: Education in correctional institutions. The Journal of Correctional Education, 58(2), 157-169.

Berry, D. (2005). Methodological pitfalls in the study of religiosity and spirituality. Western Journal of Nursing Research, 27(5), 628-647. https://doi. org/10.1177/0193945905275519.

Cooper, A. D., Durose, M. R., \& Snyder, H. N. (2014). Recidivism of inmates released from 30 states in 
2005: Patterns from 2005 to 2010. Washington: US Department of Justice, Bureau of Justice Statistics. Retrieved from https://www.bjs.gov/content/pub/ pdf/rprts05p0510.pdf.

Hamanongan, J. (2018). Dua pelaku yang curi motor dan rudapaksa korban merupakan residivis. Retrieved from http:/www.tribunnews.com/ metropolitan/2018/08/14/dua-pelaku-yang-curimotor-dan-rudapaksa-korban-merupakan-residivis.

Huberman, M., \&Miles, M. B. (2002). The qualitative researcher's companion. California: Sage Publications.

Huss, M. T. (2008). Forensic psychology. New Jersey: Wiley.

Iriani, D. (2019). Penegakan hukum dan kesadaran hukum narapidana wanita di lapas Ponorogo. Kodifikasia: Jurnal Penelitian Islam, 13(1), 163-181. https://doi. org/10.21154/kodifikasia.v13i1.1680.

Johnson, B. R., DeLi S., Larson, D. B., \& McCullough, M. (2000). A systematic review of the religiosity and delinquency literature: A research note. Journal of Criminal Justice 16(1), 32-53. https://doi.org/10.11 77\%2F1043986200016001003.

Kartono, K. (2011). Patologi sosial jilid 1. Jakarta: PT Rajagrafindo Persada.

LaCourse, A., Listwan, S. J., Reid, S., \& Hartman, J. L. (2019). Recidivism and reentry: The role of individual coping styles. Crime and Delinquency, 65(1), 46-68. https://doi.org/10.1177/0011128718790497.

Madia, F. (2018). Rampok nasabah hingga Rp.714 juta komplotan residivis diringkus. Retrieved from https://www.idntimes.com/news/indonesia/ fitria-madia/rampok-nasabah-hingga-rp714-jutakomplotan-residivis-diringkus/full.

Maryanto., Rahmawati, D., \& Rini, I. (2014). Pelaksanaan pembinaan yang bersifat kemandirian terhadap narapidana di lembaga pemasyarakatan kelas IIB Slawi. Jurnal Pembaharuan Hukum, 1(1), 66-72. http://dx.doi.org/10.26532/jph.v1i1.1472.

Nasaruddin, N., \& Syarifuddin, S. (2018). Pola pembinaan sosial keagamaan dengan pengintegrasian nilai-nilai budaya Bima (Studi terhadap para narapidana di lembaga pemasyarakatan Bima). TAJDID: Jurnal Pemikiran Keislaman dan Kemanusian, 2(1), 297313. http://dx.doi.org/10.52266/tadjid.v2i1.103.

Ningtyas, E., Gani, A. Y. A., \& Sukanto. (2013). Pelaksanaan program pembinaan narapidana pada lembaga pemasyarakatan dalam rangka pengembangan sumber daya manusia (Studi pada lembaga pemasyarakatan klas IA Lowokwaru Malang). Jurnal Administrasi Publik Mahasiswa Universitas Brawijaya, 1(6), 1266-1275.

Prabawa, I. M. A., \& Suardana, I. W. (2020). Pengaturan pembinaan narapidana residivis terhadap anak dibawah umur. E-Jurnal Ilmu Hukum Kertha Wicara, 8(9), 1-17.

Republik Indonesia. (1995). Undang-Undang nomor 12 tahun 1995 tentang Pemasyarakatan. Jakarta: Kementrian Hukam dan Hak Asasi Manusia Republik Indonesia.

Ruggero, T., Dougherty, J., \& Klofas, J. (2015). Measuring recidivism definitions, errors, and data sources. Rochester: Centre for Public Safety Initiatives. Retrieved from https://www.rit.edu/ liberalarts/sites/rit.edu.liberalarts/files/documents/ our-work/2015-03\%20-\%20Measuring\%20 Recidivism \% 20-\%20Definitions\%2C\%20 Errors\%2C\%20and\%20Data\%20Sources.pdf .

Sudarto. (2010). Kapita selekta hukum pidana. Bandung: Alumni Sugiyono.

Sumter, M., Wood, F., Whitaker, I., \& Berger-Hill, D. (2018). Religion and crime studies: Assessing what has been learned. Religions, 9(6), 1-15. https://doi. org/10.3390/rel9060193.

Susetyo, H. (2013). Sistem pembinaan narapidana berdasarkan prinsip restorative justice. Jakarta: Badan Pembinaan Hukum Nasional.

Tjahjati, E. (2012). Perlindungan dan pembinaan terhadap Warga Binaan Pemasyarakatan (WBP) (Study di lembaga pemasyarakatan anak kelas IIA Blitar). Jurnal Ilmu Hukum, MIZAN, 1(2), 55-62.

Utami, P. N. (2017). Keadilan bagi narapidana di lembaga pemasyarakatan. Jurnal Penelitian Hukum De Jure, 17(3), 381-394. https://doi.org/10.30641/ dejure.2017.v17.381-394.

Wardhani, N. S., Hartati, S., \& Rahmasari, H. (2016). Sistem pembinaan luar lembaga bagi narapidana yang merata dan berkeadilan berperspektif pada tujuan pemasyarakatan. Jurnal Hukum \& Pembangunan, 45(1), 1-32. http://dx.doi.org/10.21143/jhp.vol45. no1.7.

Wulandari, S. (2012). Efektifitas sistem pembinaan narapidana di lembaga pemasyarakatan terhadap tujuan pemidanaan. Serat Acitya (Jurnal Ilmiah), 1(1), 131-142. 